\title{
APRESENTAÇÃO UM DIÁLOGO ENTRE CAMPOS
}

Desta vez, a Revista Fragmentum colocou em diálogo a Literatura e a Filosofia, não que a Filosofia não seja também Literatura e que a Literatura não possa ser também filosófica, mas porque, em um mundo cada vez mais prenhe de divisôes e fronteiras, de espaços de exclusividade e caminhos fechados, se esquece, a nosso ver, de que a criação humana transcende sempre todas essas fronteiras e divisóes, fazendo, de cada caminho fechado, uma via aberta para a alteridade.

Nesta direção, concordamos que a criação humana acontece, por um lado, no mais íntimo de cada sujeito, mas, na medida em que se concretiza, transpassa sempre esse espaço de subjetividade, desdobrando-se em efeitos, ecos e ressonâncias de que não se têm controle algum. São os sentidos em jogo, dados pela língua, que reverberam e que se deslocam de modo pouco ou nada linear - afinal, estamos no campo da linguagem, onde criar confusóes, confissōes e poeturas é tarefa recorrente.

Defendeu um autor, um poeta-filósofo português do século XX, Teixeira de Pascoaes (1893-1953), que o filósofo e o poeta não poderiam habitar "espaços separados". Também no Brasil, encontramos diversos autores cuja obra personifica bem essa ponte entre a Literatura e a Filosofia. Pensamos, nomeadamente, em Clarice Lispector e Guimaráes Rosa - mas outros exemplos, porventura até mais óbvios, poderiam ser referidos. Foram e são eles a nos dar a dimensão das dobraduras da língua sob si mesma e dos temas filosóficos entranhados nos enredos de vida e morte dos personagens.

Sabemos que a Fragmentum não fragmenta - pelo contrário, agrega, cria pontes. Aqui estáo os pontos de vista de algumas delas que cada um dos autores foi capaz de estabelecer nos fragmentos e contributos que nos ofereceu. Há trabalhos teóricos sobre os entremeios do Discurso e da Psicanálise, outros ligados ao campo da História das Ideias Linguísticas, outros, ainda, sobre a obra de autores portugueses visitados a partir da lente da Filosofia. O que se deposita nesta edição é um enlace entre a voz e os trabalhos de pesquisadores brasileiros e portugueses, que se encontram há tempos com a instância do poético, seja tendo seu observatório no campo da teoria discursiva, seja na investigaçáo de temas filosóficos, seja nas análises literárias. Com diferentes percursos teórico-analíticos, as voltas e reviravoltas do humano estão postas na mesa, em jogo tenso e deslocante que não cessa de nos encantar; estâo, também, servidas para que os encontros de campos 
sejam vistos e saboreados como aqueles frutos encontrados nas zonas de fronteira e nos atalhos que o poeta Manoel de Barros qualifica como os melhores. Concordamos com ele. Entremos, então, para degustar as palavras servidas.

Maria Celeste Lopes Natário (UP - Portugal) Lucília Maria Abrahão e Sousa (USP-RP) 